\title{
Characterization of Extraceluller Chitinase Produced by Bacillus licheniformis JP2 from Penen Hot Springs, North Sumatera
}

\author{
Jane Melita Keliat ${ }^{1, ~ *}$, Dwi Suryanto ${ }^{2}$, Erman Munir ${ }^{2}$ \\ ${ }^{1}$ Faculty of Agriculture, University of Nahdlatul Ulama Sumatera Utara, Medan, North Sumatera, Indonesia \\ ${ }^{2}$ Department of Biology, Faculty of Mathematics and Natural Sciences, University of Sumatera Utara, Medan, North Sumatera, Indonesia
}

Email address:

jane310189@gmail.com (J. M. Keliat)

*Corresponding author

\section{To cite this article:}

Jane Melita Keliat, Dwi Suryanto, Erman Munir. Characterization of Extraceluller Chitinase Produced by Bacillus licheniformis JP2 from Penen Hot Springs, North Sumatera. Frontiers in Environmental Microbiology. Vol. 2, No. 5, 2016, pp. 24-27.

doi: $10.11648 /$ j.fem.20160205.11

Received: September 13, 2016; Accepted: October 7, 2016; Published: November 8, 2016

\begin{abstract}
The research was about characterization of extraceluller chitinase produced by Bacillus licheniformis JP2 from Penen Hot Springs, North Sumatera. Precipitation of crude chitinase was performed with different levels of ammonium sulphate. Chitinase activity was determined colorimetrically by detecting the amount of N-acetylglucosamine (GlcNAc) released from colloidal chitin substrate with $\mathrm{N}$-acetylglucosamine. Characterization of chitinase activity was measured at different $\mathrm{pH}$, different temperature, $\mathrm{K}_{m}$ and $\mathrm{V}_{\max }$ values. The optimum activity of chitinase was produced 4 days after incubation with chitinase activity of $0.0063 \mathrm{U} / \mathrm{ml}$. Optimum chitinase activity was higher after $50 \%$ ammonium sulphate precipitation with activity of $0.0087 \mathrm{U} / \mathrm{ml}$ followed by decreasing in activity supernatant with activity of $0.0012 \mathrm{U} / \mathrm{ml}$. Chitinase activity increased at $\mathrm{pH} 6$ and at $60^{\circ} \mathrm{C}$ by $0.05066 \mathrm{U} / \mathrm{ml}$ with specific activity $3.8113 \mathrm{U} / \mathrm{mg}$ after dialysis. $\mathrm{K}_{m}$ and $\mathrm{V}_{\max }$ values were $0.321 \mathrm{mg} / \mathrm{ml}$ and $71.429 \mu \mathrm{g}$, respectively.
\end{abstract}

Keywords: Bacillus licheniformis, Chitinase, Thermophilic

\section{Introduction}

Nowadays, chitinase is one of popular enzyme. Chitinase are known to be produced by bacteria and fungi obtained from various sources such as the rhizosphere and filosfer, soil or water environments such as oceans, lakes, ponds, or shrimp waste [12]. Chitinolytic bacteria is not only found in mesophyll environment, but also find in the termophile environment such as Bacillus licheniformis MB-2 is obtain from Tompaso Lake, North Sulawesi [1]. Bacillus sp. HU1 was obtained from Xinjiang hot springs in China [2].

Hot springs of Ranau lake was obtained genus Bacillus which have an activity chitinolytic [8], and Stenotrophomonas maltophila produce thermostable chitinase from soil in Jamia Hamdard, New Delhi [14].

Chitinase hold a lot of importance in various fields. In the pharmaceutical field, result of chitin hydrolysis such as kitooligosakarid could be useful because it was found anti- tumor activity [15]. Chitinase has ability to degrade shrimp waste contained chitin [16], in agriculture, chitinase use as controlling plants diseases [11]. The purified chitinase from C. cellulans strain 191 presents potential for application in fungal control and protoplast formation such as Rhizopus oligosporus, Mucor miehei, Penicillium sp., Streptomyces phaerochromogenes, Trichoderma viride [3].

Many efforts to screen bacteria that have ability to produce high chitinase. From the previous studies, there was the activity of chitinase producing bacteria isolated from Penen Hot Springs, North Sumatera. The highest index chitinolitic was isolate JP2 by 1.65 . The results showed that the molecular identification of isolates JP2 was Bacillus licheniformis. This study aimed to produce and purify chitinase from Bacillus licheniformis JP2 followed by its characterization on the basis of $\mathrm{pH}$, temperature, $\mathrm{K}_{m}$ and $\mathrm{V}_{\max }$ values. 


\section{Materials and Methods}

\subsection{Culture Conditions for Chitinase Production}

Bacillus licheniformis JP2 were isolated from Penen Hot Springs, North Sumatera. Studies have been previously carried out to Bacillus licheniformis JP2 for its ability in producing chitinase. The culture medium was composed of $0.3 \mathrm{~g} \mathrm{KH}_{2} \mathrm{PO} 4,0.7 \mathrm{~g} \mathrm{~K}_{2} \mathrm{HPO}_{4}, 0.5 \mathrm{~g} \mathrm{MgSO}_{4} .7 \mathrm{H}_{2} \mathrm{O}, 0.001 \mathrm{~g}$ $\mathrm{ZnSO}_{4}, 0.001 \mathrm{~g} \mathrm{MnCl}_{2}, 0.01 \mathrm{~g} \mathrm{FeSO}_{4} \cdot 7 \mathrm{H}_{2} \mathrm{O}$ in $1000 \mathrm{ml}$ containing $2 \%(\mathrm{w} / \mathrm{v})$ colloidal chitin, $\mathrm{pH} 7$ added $0.15 \mathrm{~g}$ yeast extract. Unless it mentioned, all bacterial cultures were incubated at $55^{\circ} \mathrm{C}$ in waterbath shaker $120 \mathrm{rpm}$.

\subsection{Cell Growth and Crude Chitinase Activity}

Eight flasks containing culture media were inoculated with Bacillus licheniformis JP2 and incubated for 8 days. Observation of cell growth and measurement of chitinase activity was conducted every 24 hours. Cell growth was observed as optical density at $\lambda=600 \mathrm{~nm}\left(\mathrm{OD}_{600}\right)$. Culture broth was centrifuged at $10,000 \mathrm{rpm}$ for 10 minutes at $4{ }^{\circ} \mathrm{C}$. Enzyme assay was conducted by mixing $150 \mu 1$ supernatant, $150 \mu \mathrm{l}$ sodium phosphate, buffer of $\mathrm{pH} 7$ and $300 \mu \mathrm{l}$ of $3 \%$ colloidal chitin incubated at $55^{\circ} \mathrm{C}$ for 30 minutes. The mixture was centrifuged at 10,000 rpm for 5 minutes. $300 \mu \mathrm{l}$ supernatant was added with $700 \mu \mathrm{l}$ aquadest and $1000 \mu \mathrm{l}$ schales solution $\left(0.5 \mathrm{~g} \mathrm{~K}_{3}(\mathrm{FnCn})_{6}\right)$ in 0.5 sodium carbonate). Solution was mixed and boiled for 10 minutes. Chitinase activity was determined colorimetrically by detecting the amount of $\mathrm{N}$-acetylglucosamine (GlcNAc) released from colloidal chitin substrate with $\mathrm{N}$-acetylglucosamine as a reference compound at $\lambda 420 \mathrm{~nm}[20]$.

\subsection{Determination of Protein Concentration}

Protein concentration was determined by Bradford (1976) [5] method using bovine serum albumin as the standard and absorbance was measured at $595 \mathrm{~nm}$.

\subsection{Partial Purification of Chitinase}

Bacillus licheniformis JP2 was cultured in $1000 \mathrm{ml}$ culture media for 4 days. The culture broth was centrifuged at 10,000 rpm for 10 minutes at $4^{\circ} \mathrm{C}$. The ammonium sulphate saturation from $20 \%$ until $70 \%$ was added slowly to the enzyme solution and left at $4{ }^{\circ} \mathrm{C}$ for at least $3 \mathrm{~h}$ with vigorous stirring. Then the solution was centrifuged at $10,000 \mathrm{rpm}$ for 15 minutes. The culture remain was used for enzyme characterization after the highest activity of ammonium saturation was known. The result of precipitation was centrifugated to separated enzyme precipitation from supernatant. The enzyme was resuspended in $1 \mathrm{ml}$ of $10 \mathrm{mM}$ phosphate buffer of $\mathrm{pH}$ 7.0. Precipitated enzyme and supernatant were stored at $4^{\circ} \mathrm{C}$ overnight and subjected to chitinase activity assay. For enzyme characterization, enzyme precipitated with 50\% ammonium sulphate was dialysed against the same buffer, since it showed higher chitinase activity. It was subjected to extensively dialysed for 24 hours at $4^{\circ} \mathrm{C}$ and adding of the buffer.

\subsection{Characterization of Chitinase}

Chitinase was characterized by optimum temperature and optimum $\mathrm{pH}$. Chitinase activity was assayed at different $\mathrm{pH}$ values ( $\mathrm{pH} 4$ to 8 ) using different buffer $50 \mathrm{mM}$ such as acetic buffer ( $\mathrm{pH} 4-6)$, sodium phosphate buffer $(\mathrm{pH} 7)$, tris- $\mathrm{HCl}$ buffer (pH 8-9) at $37^{\circ} \mathrm{C}$. Chitinase preparation was incubated at temperature ranging from $35^{\circ} \mathrm{C}, 40^{\circ} \mathrm{C}, 45^{\circ} \mathrm{C}, 50^{\circ} \mathrm{C}, 55^{\circ} \mathrm{C}$, $60^{\circ} \mathrm{C}, 65^{\circ} \mathrm{C}, 70^{\circ} \mathrm{C}$ at $\mathrm{pH}$ 6. The effect of substrate concentration on chitinase activity was determined at different concentrations of colloidal chitin varying between $0.1 \%, 0.2 \%, 0.3 \%, 0.4 \%, 0.5 \%, 0.6 \%, 0.7 \%, 0.8 \%, 0.9 \%$ and $1 \%$. The $K_{m}$ and $V_{\max }$ values were accounted from a double reciprocal plot by the Lineweaver-Burk method

\section{Results and Discussion}

\subsection{Production of Bacillus Licheniformis JP2 Chitinase}

Bacillus licheniformis JP2 produced termostable chitinase at 4 days of incubation. The optimum activity was 0.0087 $\mathrm{U} / \mathrm{ml}$ and tend to decrease thereafter (figure 1). Other studies showed the similar result. Bacillus licheniformis A2 showed optimum production of chitinase at 4 days [6]. Bacillus subtilis showed to have higher chitinase activity in 4 days [17] and 4 days for Bacillus atrophaeus, respectively [21].

Bacteria have different ability to produce chitinase. Its depend on gene encoding chitinase. Other studies showed bacteria Bacillus licheniformis A35 produced highest chitinase activity in 6 days [6] Bacillus licheniformis MB-2 showed to have chitinase activity in 6 days with $0,26 \mathrm{U} / \mathrm{ml}[1]$.

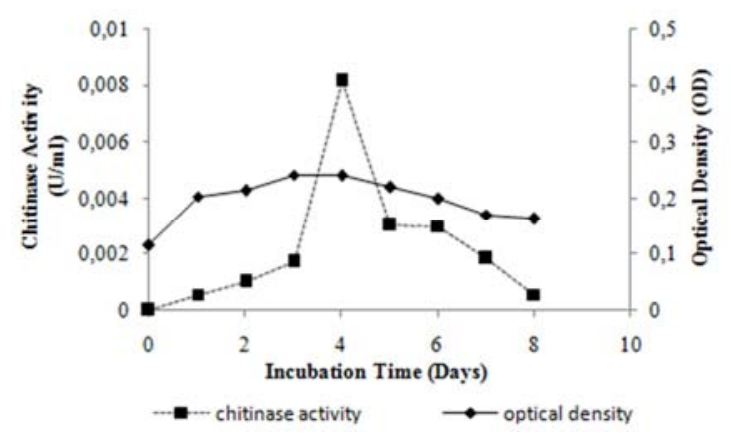

Figure 1. Bacillus licheniformis JP2 cell growth in accordance with its chitinas activity.

\subsection{Purification and Chitinase Activity of Bacillus Licheniformis JP2}

Bacillus licheniformis JP2 produced chitinase with colloidal chitin as $\mathrm{C}$ sole source. Chitinase activity of pellet tended to increase when supernatant decrease by using ammonium sulphate precipitation (20-70\%). Optimum chitinase activity was obtained at $50 \%$ ammonium sulphate (figure 2). Other studies showed the similar results. Optimum chitinase activity of Bacillus sp. BK 17 from Bangka [19] and Bacilus subtilis 13.26 was at $50 \%$ ammonium sulphate [13]. The water molecules released by using 50\% ammonium sulphate saturation followed by binding protein. 


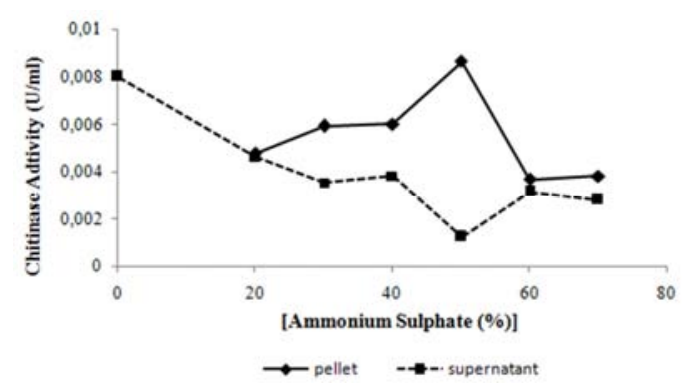

Figure 2. Chitinase activity of supernatant and pellet after ammonium sulphate precipitation.
The specific activity of crude chitinase showed 0.175 $\mathrm{U} / \mathrm{mg}$ protein. Ammonium sulphate showed to recover $1.833 \%$ with specific activity $0.451 \mathrm{U} / \mathrm{mg}$ protein. While dialysed enzyme showed to have specific activity of 1.040 $\mathrm{U} / \mathrm{mg}$ protein with purification fold of 5.294 and resulted to recover $2.22 \%$. The results of Bacillus licheniformis JP2 chitinase purification fold are summarized in Table.1. Levels of protein decreased during dialysis because of diffusion and osmosis process. Diffusion and osmosis of causing some proteins missing.

Table 1. The Result of Bacillus licheniformis JP2 chitinase purification.

\begin{tabular}{lllll}
\hline Purification Step & $\begin{array}{l}\text { Total Activity } \\
(\mathbf{U} / \mathbf{m l})\end{array}$ & $\begin{array}{l}\text { Total Protein } \\
(\mathbf{m g} / \mathbf{m l})\end{array}$ & $\begin{array}{l}\text { Specific activity } \\
(\mathbf{U} / \mathbf{m g})\end{array}$ & $\begin{array}{l}\text { Purification fold } \\
(\mathbf{x})\end{array}$ \\
\hline Crude Enzyme & 4,725 & 26,925 & 0,175 & 1 \\
Ammonium Sulphate & 0,087 & 0,192 & 0,451 & 2,570 \\
Dialysis & 0,105 & 0,101 & 1,040 & 100 \\
\hline
\end{tabular}

\subsection{Characterization of Bacillus licheniformis JP2 Termostable Chitinase}

The effect of $\mathrm{pH}$, temperature, and $\mathrm{K}_{m}, \mathrm{~V}_{\max }$ values on enzyme activity of Bacillus licheniformis JP2 was investigated. Chitinase activity of Bacillus licheniformis was investigated over range $\mathrm{pH} 3$ to $\mathrm{pH}$. Many bacteria showed optimum $\mathrm{pH}$ range 5-8 [21]. Some bacteria produced optimum activity at low $\mathrm{pH}$. Commonly, denaturing enzyme occured at lowest $\mathrm{pH}$ and highest $\mathrm{pH}$. In our study, optimum chitinase activity of Bacillus licheniformis JP2 was at $\mathrm{pH} 6$ (figure 3). Chitinase activity from Bacillus licheniformis MB-2 was optimum at $\mathrm{pH} 6$ [1]. Chitinase activity of thermophilic bacteria Ralstonia sp. A471 was optimum at $\mathrm{pH} 5$ [7]. Chitinase activity of Bacillus licheniformis $\mathrm{A} 2$ and A35 was optimum at $\mathrm{pH} 5$ [6].

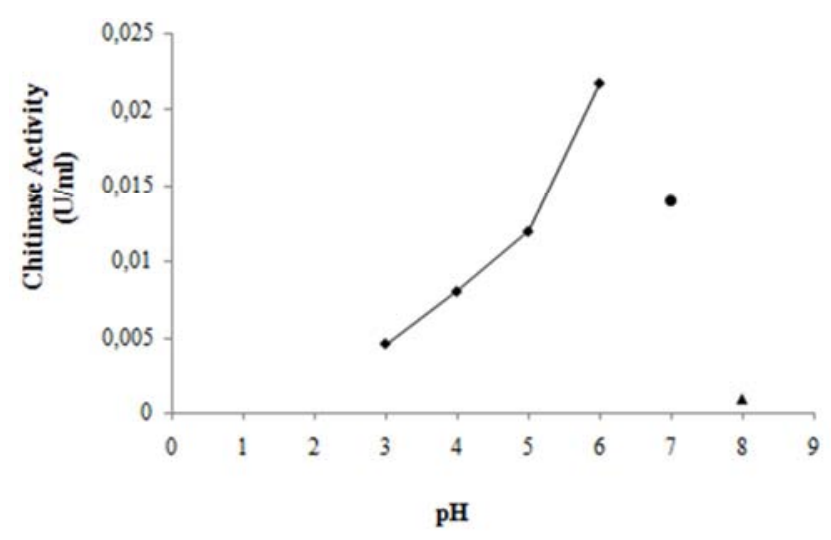

Figure 3. Optimum pH of Bacillus licheniformis JP2 chitinase activity.

JP2 isolate chitinase activity could be active at temperature range of $35^{\circ} \mathrm{C}$ to $70^{\circ} \mathrm{C}$. however chitinase thermostabil was continuously decreased either when the temperature increased. Many bacteria showed optimum temperature range from $30^{\circ} \mathrm{C}-60^{\circ} \mathrm{C}$ [21], [2]. In this study the optimum chitinase activity was obtained at $60^{\circ} \mathrm{C}$ ie $0.05066 \mathrm{U} / \mathrm{ml}$ (figure 4). Temperature related to activation energy of enzyme. When the temperature was raised it might affect the structure of enzymes and lead to reduced chitinase activity. Other studies showed Stenotrophomonas maltophilia SJ0602 [14] was isolated from soil and Bacillus sp. HS, 3-1a [4] were to have an optimum activity at $60^{\circ} \mathrm{C}$. Other bacteria Micrococcus sp. AG84 [10] and Vibrio sp 98CJ11027 [18] showed optimum temperature of $45^{\circ} \mathrm{C}$. Bacillus licheniformis $\mathrm{A} 2$ and $\mathrm{A} 35$ showed optimum temperature of $70^{\circ} \mathrm{C}[6]$.

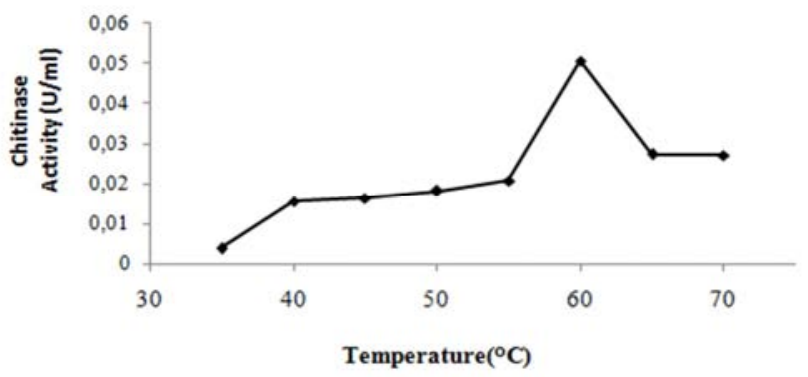

Figure 4. Optimum temperature of Bacillus licheniformis chitinase activity.

Determination of the $\mathrm{K}_{m}$ and $\mathrm{V}_{\max }$ chitinase Bacillus licheniformis JP2 was carried out by reacting chitinase of dialysis results on various substrate concentrations of colloidal chitin at $0.1 \%$ to $1 \%$ were incubated for 30 minutes $60^{\circ} \mathrm{C} \mathrm{pH} 6$ (figure 5). The value of $\mathrm{K}_{m}$ and $\mathrm{V}_{\max }$ were determined by Lineweaver-Burk's plot. Bacteria showed different $\mathrm{K}_{m}$ and $\mathrm{V}_{\max }$ values from different sources. Utilization of this chitin in different environment needs suitable chitinases producing by chitinolytic microorganisms [19]. The $\mathrm{K}_{m}$ and $\mathrm{V}_{\max }$ values of Bacillus licheniformis were $0.321 \mu \mathrm{g} / \mathrm{ml}$ and $71.429 \mu \mathrm{g} . \mathrm{K}_{m}$ and $\mathrm{V}_{\max }$ values of Enterobacter sp. NRG4 were 1,43 $\mathrm{mg} / \mathrm{ml}$ and 83,33 $\mu \mathrm{M} / \mu \mathrm{g}$ hour for chitin hydrolysis; $1,41 \mathrm{mg} / \mathrm{ml}$ and 74.0707 $\mu \mathrm{M} / \mu \mathrm{g}$ hour for colloidal chitin; $2 \mathrm{mg} / \mathrm{ml}$ and $33,33 \mu \mathrm{M} / \mu \mathrm{g}$ hour for glicol chitin [11]. The values of $\mathrm{K}_{m}$ and $\mathrm{V}_{\max }$ of Serratia marcescens B4A chitinase were $8.3 \mathrm{mg} / \mathrm{ml}$ and 2.4 $\mathrm{mmol} / \mathrm{min}$ respectively [9]. 


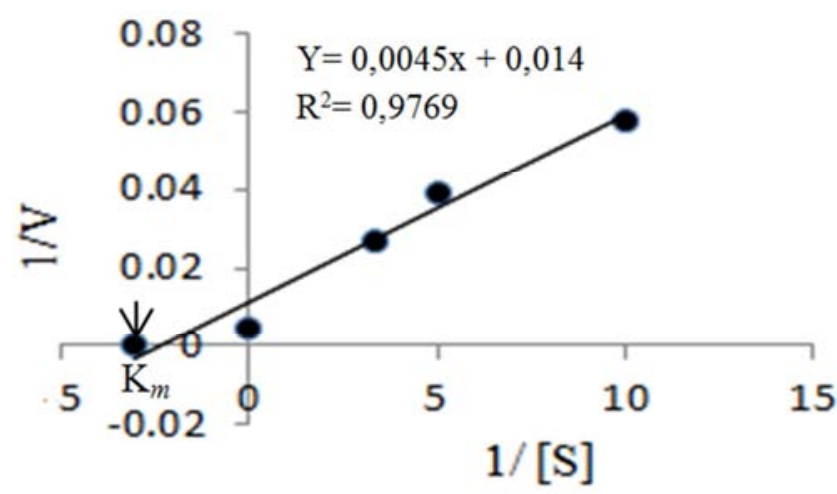

Figure 5. The activity of Bacillus licheniformis JP2 chitinase at different colloidal chitin concentration.

\section{Conclusion}

Chitin is distributed widely in nature. Many bacterial chitinase showed different optimum temperature, optimum $\mathrm{pH}, \mathrm{K}_{m}$ and $\mathrm{V}_{\max }$ values. Chitinase of Bacillus licheniformis JP2 was termostable enzyme that actived at highest temperature and low $\mathrm{pH}$. Although chitinolytic activity was characterized from variety sources, it's still important to produce chitinase with more economical values.

\section{Acknowledgments}

We would like to thank to Laboratory of Microbiology and Biochemistry, and Laboratory of Biotechnology, Inter University Center, Bogor Agriculture Institute, Bogor, Indonesia.

\section{References}

[1] A. Toharisman, M. T. Suhartono, Spindler-Bath, Hwang, and Y. R. Pyun, "Purification and Characterization of Thermostable Chitinase from Bacillus licheniformis Mb-2," J. Microb. World. Biotech, vol. 21, pp. 733-738, 2005.

[2] D. Dai, W. Hu, G. Huang, and W,. Li, "Purification and characterization of a novel extracellular chitinase from thermophilic Bacillus sp. Hu1, “ Afr. J. Biotechnol, vol. 10, no. 13, pp. 2476-2485, 2011.

[3] F. L. Fleuri, Y. H. Kawaguti, and H. H. Sato, "Production, purification and application of extracellular chitinase from Cellulosimicrobium cellulans 191," Braz. J. Microbiol, vol. 40, no. 3, pp. 623-630, 2009.

[4] H. Natsir, A. R, Patong, M. T. Suhartono, and A, Ahmad, "Production and characterization of chitinase enzymes from sulili hot springs in South Sulawesi Bacillus sp. Hsa, 3-1," Indo. J. Chem, vol. 10, no. 2, pp. 263-267, 2010.

[5] M. Bradford, "A rapid and sensitive method for the quantitation of microgram quantities of protein utilizing the principle of protein-dye binding," Anal. Biochem, vol. 72, pp. 248-254, 1976.

[6] M. Khiyami, and I. Masmali, "Characteristics of thermostable chitinase enzymes of Bacillus licheniformis isolated from red palm weavil gut," Austral. J. of Basic and Appl. Sci, vol. 2, no. 4, pp. 943-948, 2008.

[7] M. Ueda, J. Yukiko, S. Aji, N, Masami, and M, Kazutaka, "Purification and characterization of chitinase from moderately thermophilic bacterium Ralstonia sp. A-471," Biosci. Biotechnol. Biochem, vol. 69, no. 42, pp. 842-844, 2005.

[8] Muharni, "Isolation and identification of chitynolitic bacteria from Ranau Lake hot springs, South Sumatera," Jurnal Penelitian Sains, vol. 10, pp. 6-9. 2011.

[9] M. Zarei, S. Aminzadeh, H. Zolgharnaen, A. Shafahieh, A, Ghoroghi, A. Motallebi, M. Daliri, and A. S. Lotfi, "Serratia marcescens B4A chitinase product optimization using Taguchi approach," Iranian Journal of Biotechnology. vol. 8, pp. 252262. 2010.

[10] N. Annamalai, S. Giji, M. Arumugam, and T. Balasubramanian, "Purification and characterization of chitinase from Micrococcus sp. AG84 isolated from marine environment," Afr. J. Microbiol. Research, vol. 4, no. 24, pp 2822-2827, 2010.

[11] N. Dahiya, R. Tewari, P. Tewari and G. S. Honndal, "Production of an antifungal chitinase from Enterobacter sp. NRG4 and its application in protoplast production," World J. Microbiol. Biotechnol, vol. 21, pp. 1611-1616, 2005.

[12] N. Herdyastuti, J. T. Raharjo, Mudasir, and Matsjeh, "Chitinase and chitinolityc microorganism: isolation, characterization and potential," Indo. J. Chem,“" vol. 9, no.1, pp. 37-47, 2009.

[13] Purwani, "Characterization of Chitinase Thermostable 13.26," Thesis, Bogor, Agriculture Bogor Institute, 2002.

[14] R. Hamid, M. Ahmad, M. Z. Abidin, and S. Javed, "Purification and characterization of thermostable chitinase from a novel S. maltophilia strain," Malaysian J. Microbiol. Vol. 9, no. 1, pp. 7-12, 2012.

[15] R. S. Patil, V. Ghormade, and M. V. Despande, "Chytinolytic enzymes: an exploration," Enzymes and Microbiol. Technol. vol. 26, pp473-483. 2000.

[16] S. Hirano, "Chitin biotechnology applications," Biotechnol. Annu. Rev, vol. 2, pp. 237-258, 1996.

[17] S. K. Karunya, D. Reetha, P. Sararanraj and D. John, "Optimiation and purification of chitinase produced by Bacillus subtilis and its antifungal activity against plant phatogens," International journal of Pharmaceutical and Biological Archieves, vol. 2, pp. 1680-1685. 2011.

[18] S.H. Park, H. L. Jung, and K. M. Hong, "Purification and characterization of chitinase from a marine bacterium, Vibrio sp. 98CJ11027," J. Microbiol. vol. 38, no. 4, pp. 224-229. 2000 .

[19] S. Maimunah, "Characterization of Bacillus sp. BK 17", Thesis, Medan, North Sumatera University, 2013.

[20] T. Imoto, and K, Yoghisita, "A simple activity measurement of lysozyme," Agri. and Bio. Chem., vol. 35. pp. 1154-1156. 1971.

[21] V. Anuradha and K. Revathi, "Purification and characterization of chitinase from two Bacillus sp isolated from crustacean shells," Journal of Microbiology and Biotechnology Research, vol. 3, no. 3, pp. 160-167, 2013. 